RECENT MARINE SEDIMENTS OF THE CENTRAL CALIFORNIA CONTINENTAL SHELF BETWEEN POINT LOBOS AND POINT SUR

Herbert Palfrey Colomb 



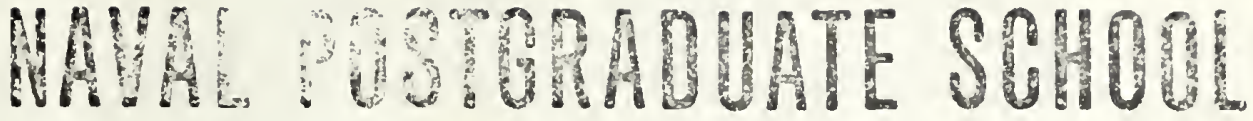 inerterey, Galifornia}
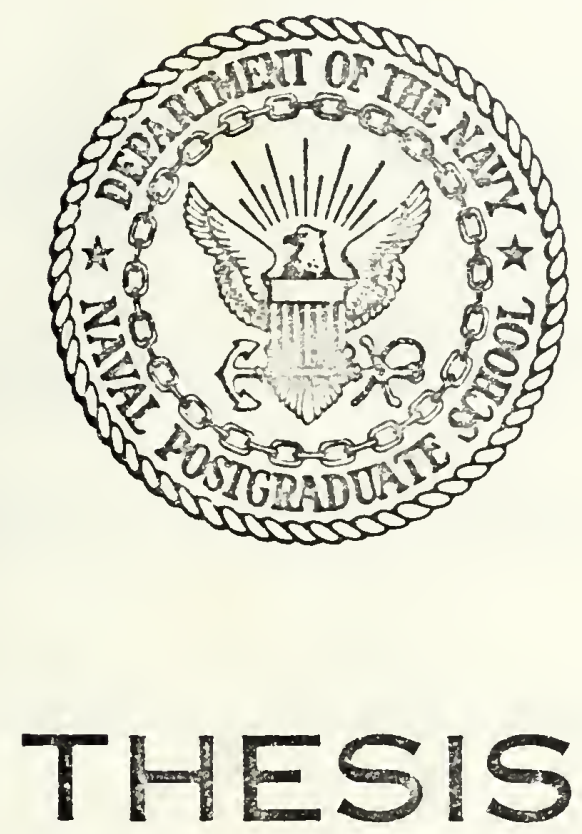

RECENT MARINE SEDIMENTS OF THE CENTRAL CAIIFORNIA CONTINENTAL SHELF BETWEEN POINT. LOBOS AND POINT SUR

$$
\text { by }
$$

HERBERT PALFPEY COLOMB, JR.

Advisor:

Robert S. Andrews

\section{March 1973}

Approved for public release; distribution unlimited. 



\title{
Recent Marine Sediments of the Central California Continental Shelf between Point Lobos and Point Sur
}

Herbert Palfrey Colomb, Jr. Lieutenant, United States Navy B.S., United States Naval Academy, 1967

Submitted in partial fulfillment of the requirements for the degree of

MASTER OF .SCIENCE IN OCEANOGRAPHY

\author{
from the \\ NAVAI POSTGRADUATE SCHOOL \\ March 1973
}





\section{ABSTRACT}

Seventy sediment samples were collected from the continental shelf between Pt. Lobos and Pt. Sur for textural analysis to determine their statistical properties. Based upon the parameters of mean grain-size, standard deviation, and skewness, three distinct belts of sediment were found. Along the coast the sediments were composed of medium sandsized, moderately to well sorted particles. Down the center of the shelf a discontinuous band of fine sand occurs in depths of 35 to $65 \mathrm{fm}$. The outer $b$ and appears to follow the break in the continental shelf and is composed of relatively coarse sediment.

Two bathymetric and $3.5 \mathrm{kHz}$ seismic profiling cruises were made through the area. The results of these cruises indicate that the offshore extension of the Palo Colorado Fault follows a branch of the Carmel Submarine Canyon.

The primary source of sediments appears to be weathering of coastal rock formations, with sediment distribution due to wave action. 



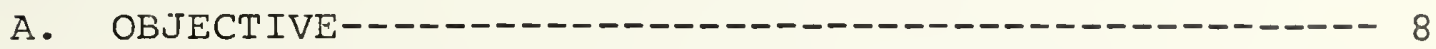

B. AREA DESCRIPTION--

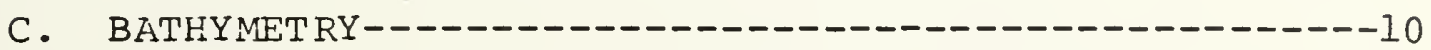

D. REGIONAL GEOLOGY--------------------------10

E. PREVIOUS WORK------

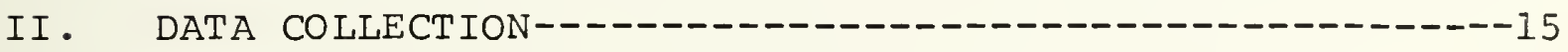

A. SAMPLE COLLECTION---------------- ----------15

B. PRECISION DEPTH RECORDING------

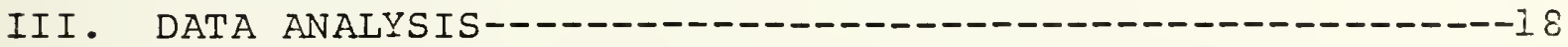

A. MECHANICAL GRAIN-SIZE ANALYSIS PROCEDURE---------I8

B. COMPUTER ANALYSIS OF RAW DATA-- -

C. BATHYMETRIC PROFILES--

IV. PRESENTATION OF DATA-- -

A. TEXTURE OF SEDIMENTS----

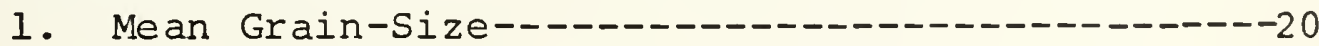

2. Standard Deviation--

3. Skewness--------- - - - - - - - - - - - - - - - - -27

4. Bimodal Distributions----

B. PEBBLE COMPOSITION--

C. SHELL CONTENT---- -------------------32

D. BATHYMETRY----

V. SUMMARY AND CONCLUSIONS---

VI. SUGGESTIONS FOR FURTHER STUDY-- 

BIBLIOGRAPHY-_-_- 39 INITIFI DISTRIBUTION IIS' FORM DD 1473 



\section{LIST OF IIGURES}

1. Bathymetry from Monterey Bay to Point Sur-.--

2. Regional Geology--

3. Location of Sample Stations----

4. Mean Grain-Size Distribution-----

5. Tertiary Diagram: Gravel-Sand-Silt Relationships------25

6. Mean Grain-Size vs Depth--

7. Standard Deviation Distribution------

8. Mean Grain-Size vs Standard Deviation--_-_-

9. Skewness Distribution-

10. Mean Grain-Size vs Skewness------------------- 31

11. Bimodal Sample Distribution---------------------.33

12. Offshore Extension of Palo Colorado Fault and

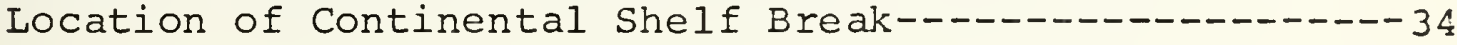

13. Precision Depth Recorder Profile Showing Fault

Scarp and Shelf Break-_- 35 



\section{LIST OF TABLES}

I. Explanation of Geologic Abbreviations--

II. Sample Locations, Gravel-Sand-Silt Relationships, and Size Statistics-n- 

The author is decply grate $=$ ul for the assistance of Dr. Robert S. Andrews of the Eppartment of Oceanography, Naval Postgraduate School, Monterey, California. Sample collection was facilitatsd is the arsistance of the Master and crew of the Research Vesse: AcANiA.

Acknowlecigenent must aljo be made to my wife, Jill colomb, for her assistance and cooperation. 



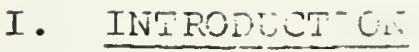

\section{A. OBJECTIVE}

The objective of this study was to describe and explain the distribution of recent marine sediments along the Central California continental shelf between Point Lobos and Point Sur. In order to accomplish this objective a total of 70 sediment stations were sampled from the Naval Postgraduate School Research Vessel ( $R / V)$ ACANIA.

\section{B. AREA DESCRIPTION}

The area of investigation is located along the Central California coast $125 \mathrm{~km}$ south of San Francisco. Carmel Bay represents the northern limit of the area, and the southern boundary is the continental shelf seaward of the Pt. Sur tombolo (Fig. 1). The Carmel and Monterey Submarine Canyons to the north and the sur submarine Canyon to the south of Pt. Sur isolate this shelf section from most littoral sediment sources. The eastern boundary is the shoreline and the western edge of the area is the $100 \mathrm{fm}$ curve.

The topography of the onshore area is rugged and mountainous. Rising abruptly from Carmel Bay and running southward along the coast, the Santa Lucia Range forms an effective drainage divide. A maximum separation between the coastline and the Santa Lucia Range exists at Pt. Sur, where the divide is found $16 \mathrm{~km}$ inland. Several youthful, perennial streams drain into the area, with the largest being the sur and 



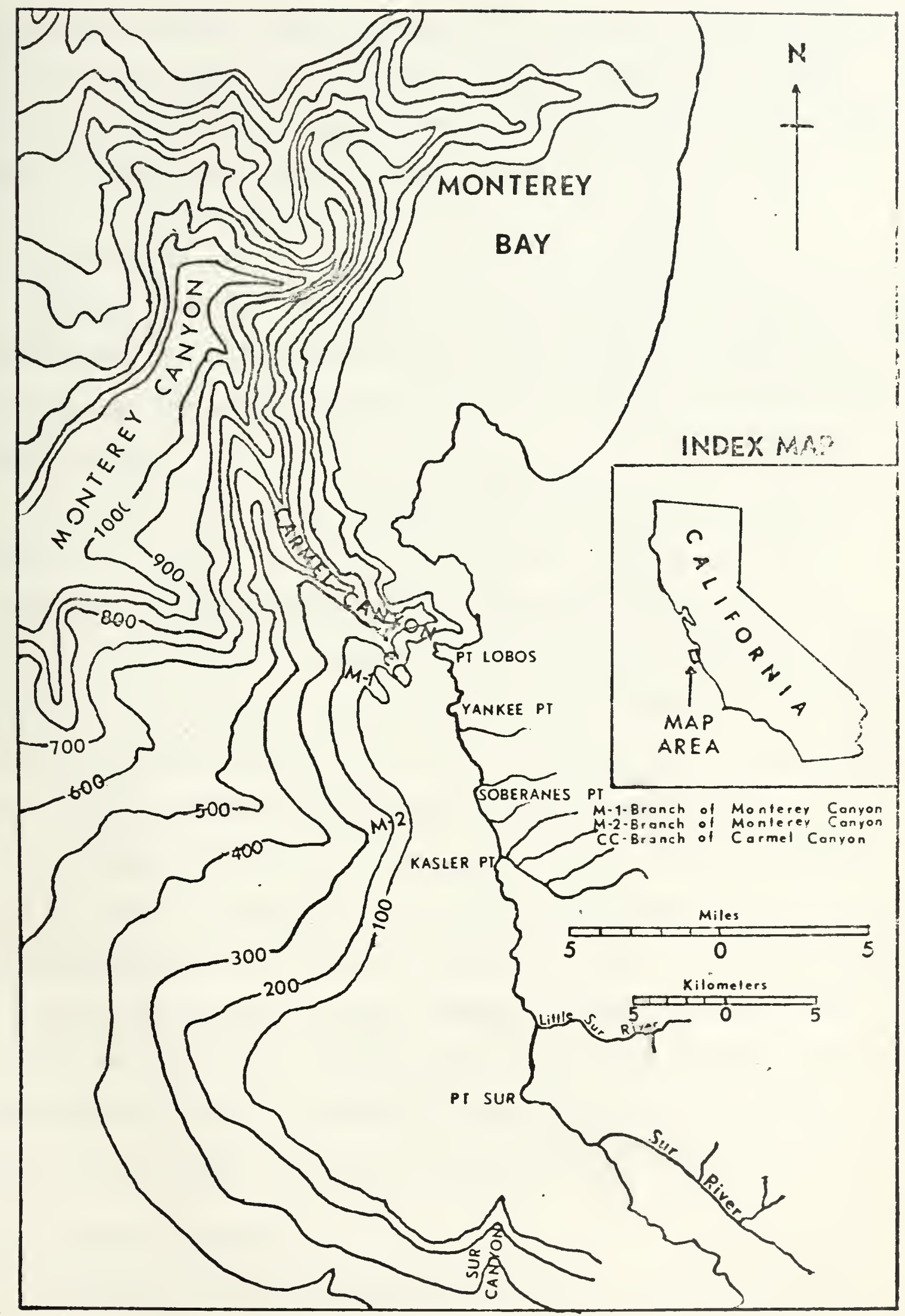

Fig. I Bathymetry from Nonterey Bay to Pt. Sur 

Littie sur Rivers. Along the coast a series of terraces can be seen extending to a height of $175 \mathrm{~m}$ between the promointories. Alluvial deposits resting on wave-cut terraces are observed along the coast (Trask, 1926).

\section{BATHYMETRY}

Dohrenwend (1971) studied the bathymetry of the area and found that $90 \%$ of the area could be described as relatively smooth and featureless with a slope of about $1.5^{\circ}$ out to the shelf break.

The major features of the area are two branches of the Monterey Canyon, a branch of the Carmel Canyon, and the relatively broad expanse of the continental shelf off of. Pt. Sur. The canyon branches mentioned are labeled M-1, M-2, and $\mathrm{CC}$, respectively, on Fig. 1. Approximately $1.5 \mathrm{~km}$ west Point Lobos the branch (CC) of the Carmel Canyon intersects the shelf, draining northward into the Carmel Canyor. The first branch $(\mathrm{M}-1)$ of the Monterey Canyon crosses the shelf $3.5 \mathrm{~km}$ west of Yankee Point and runs northwest for $3 \mathrm{~km}$ before turning westward to join the Monterey Canyon. A secona branch (M-2) of the Monterey Canyon extends almost due west from the center of the area. Finally, the wide shelf off Pt. Sur can be assumed to be the result of the northwestward movement of the block south of the sur Fault described by Trasik (1926).

\section{REGIONAL GEOLOGY}

The geology of the quadrangle inland from the area of investigation was described by Trask (1926). Cretaceous Santa 

Lucia Formation granitic rocks predominate in the northern sector down to the Palo Colorado Fault (Fig. 2). In the extreme northern part of the area the Santa Lucia occurs as a porphyritic granodiorite with orthoclase feldspar phenocrysts ranging from 3 to $10 \mathrm{~cm}$, grading rapidly southward into the main quartz diorite of the region. Farther south the mass terminates in a series of broad tongues extending into schist. South of the Palo Colorado Fault the pre-Cretaceous sur series contains the oldest rocks in the region in the form of a metamorphic series of schists, quartzites, gneisses, and crystalline limestones of sedimentary origin. Extending southward from the mouth of the Little Sur River is a 3-km wide outcropping of pre-Cretaceous Franciscan rocks composed primarily of sandstones, radiolarian chert, dark grey shales, schist, and greenstones and serpentines.

The structural geology of the quadrangle is characteri ed by a series of nearly parallel faults which extend offshor at small angles from the coastline. All of the faults har: a northwest trend and all, except the sur Fault, dip $40^{\circ}$ to $70^{\circ}$ northeast.

Near the coastline the offshore geology conforms with that found onshore. In the northeast, the Santa Lucia quartz diorite terminates at what appears to be an extension of the Palo Colorado Fault. South and west of the Santa Lucia Formation, an area of faulted Tertiary and Quaternary marine sediments are found. 



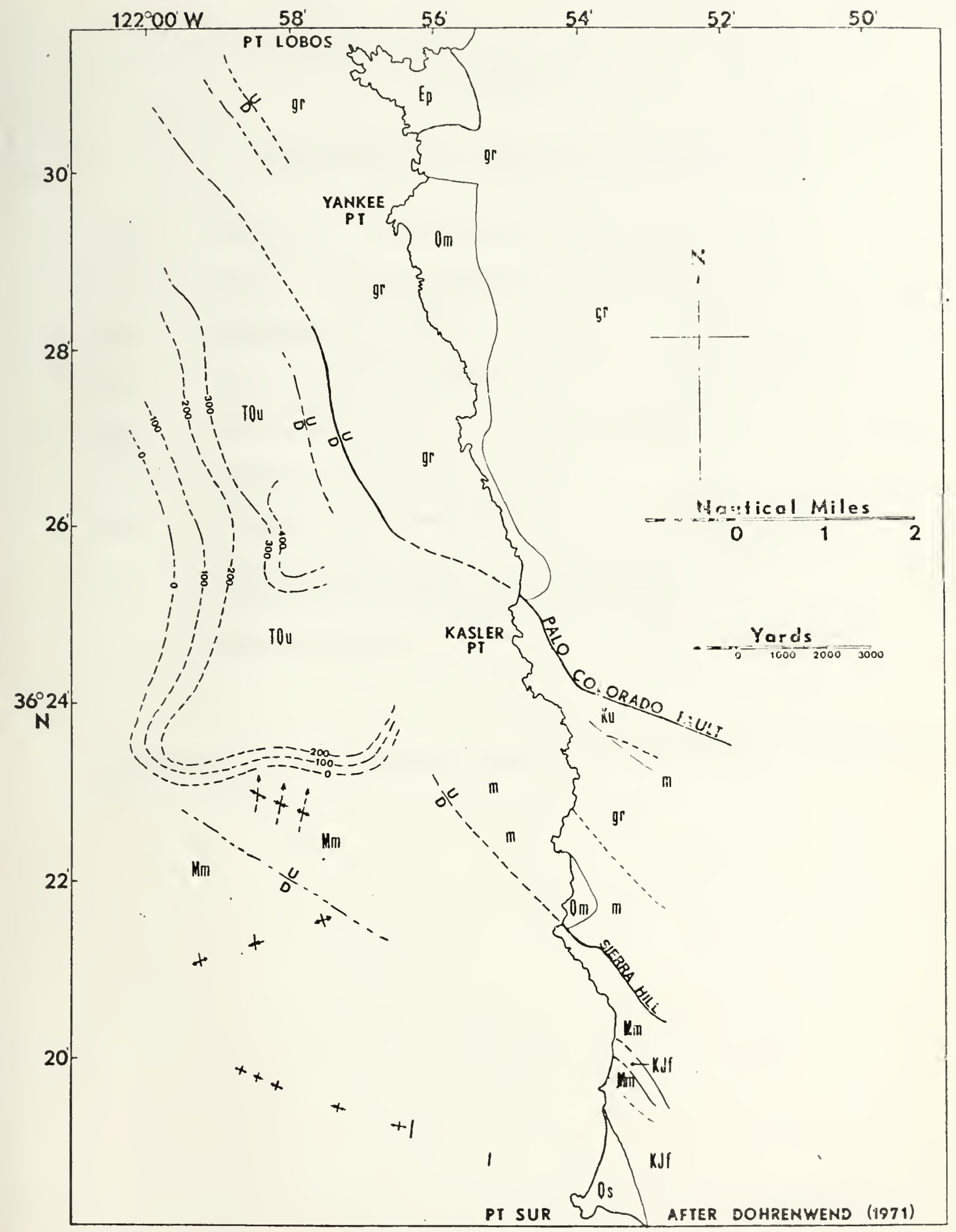

Fig. 2 Regional Geology (geologic abbreviations listed in Table I) 



\section{TABLE I}

\section{EXPLANATION OF GEOLOGIC ABBREVIATIONS}

$\begin{array}{ll}\text { TQu } & \text { Tertiary - Quaternary undifferentiated } \\ \text { Mm } & \text { Miocene marine (Monterey Formation) } \\ \text { Qm } & \text { Pleistocene marine } \\ \text { Qs } & \text { Quaternary dune sand } \\ \text { Ep } & \text { Paleocene marine (Carmelo Formation) } \\ \text { Ku } & \text { Upper Cretaceous marine } \\ \text { KJf } & \text { Franciscan Assemblage } \\ \text { gr } & \text { Cretaceous granitic rocks (Santa Lucia } \\ & \text { granodiorite and quartz diorite) } \\ \text { m } & \text { Pre-Cretaceous metamorphic rocks (Sur Series) }\end{array}$

Sedimentary rock isopach contour line (meters) ----400--- 

The northwest-southeast trend found in the Santa Lucia Range continues in the offshore formations. There is evidence of much faulting throughout the area which appears to be a continuation of onshore faults (Dohrenwend, 1971).

E. PREVIOUS WORK

The geology of the onshore area of the study has been well described by Trask (1926). Very little bathymetric or geologic work has been completed in the offshore area of investigation. A bathymetric chart has been compiled by the Coast and Geodetic Survey (C.\&G.S. 5476) and a recent seismic survey was conducted by Dohrenwend (1971). Studies of oceanographic features are almost non-existent. 



\section{DATA COLLECTION}

\section{A. SAMPLE COLLECTION}

Seventy samples were collected between Pt. Isobos and Pt. Sur by ship, using a shipek grab sampler. Ir Ia.dar: 1972 a reconnaissance was conducted during whi.ch 15 sampjes were

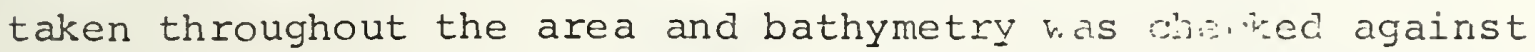
the existing navigational chart (C.\&G.S. 5476). ivavigation was performed by the master of the research vassel and sample depth was obtained by fathometer. Based wo. the results of the reconnaissance, 55 additional stations re ampled (Fig. 3).

Samples were not recovered from each station. but rock dwelling organisms were present in the sampler bucket when no sediment was collected. The R/V ACAIIA, used for sample collection, is small enough for easy maneuvering, yet has the stability for good navigation and safe platform work.

Grab samples were tagged, placed in double piastic bags, and refrigerated until processed. Any rock fragments collected were saved for future analysis.

\section{B. PRECISION DEPTH RECORDING}

In conjunction with $3.5 \mathrm{kHz}$ seismic reflection profile and bathymetric studies being conducted in the vicinity of the study area, two traverses of the study area were made by oceanographic research vessels, USNS BARTLETT and USNS DE STEIGUER. The equipment onboard the two vessels was almost identical. 



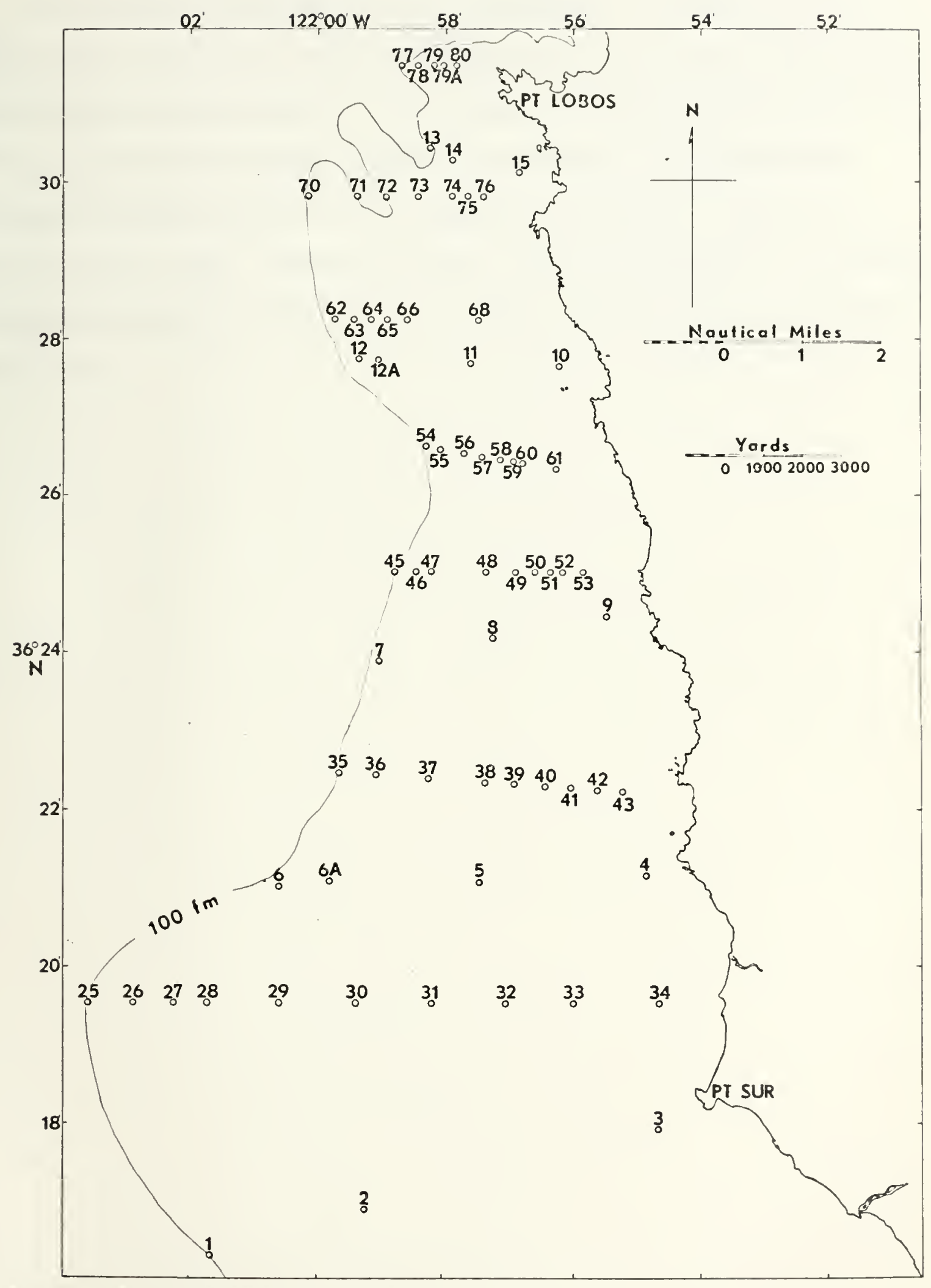

Fig. 3 Location of Sample Stations 

The primary mission of the bathymetry transects was to delineate the break in the continental shelf and to plot the location of any possible fault scarps. Within the study area, the cruise of the USNS BARTLETT confirmed the fathometer depths recorded during grab sampling and gave a broad overview of the area. Several tracks from the cruise of the USNS DE STEIGUER were helpful in tracking the Palo Colorado Fault northward. 



\section{DATA ANALYSIS}

\section{A. MECHANICAL GRAIN-SIZE ANALYSIS PROCEDUEZ}

Krumbein and Pettijohn (1938) outiined the procedures followed in the grain-size analys : . a duck d for this investigation. Large subsamples of $2: \because: 3,1,9$ were taken from each grab sample to insure that suficicont 3- and 4- $\varnothing$ fractions would be obtained for later heary mix.ai analysis. Any sample with a total weight of iess than :00 or made up predominately of pebbles was analyzed in its entiret?.

Each subsample was shaken with aistilied water in a 500-ml jar to desalt. After being allowed is settie, the excess water was decanted by siphon. Foilr: process, the subsample was wet-seived through a $4 \not$ screen thereby removing the silt- and clay-sjze fractions from the sand-gravel-size fractions remaining in the screen. After passing through the screen, the fine fraction was transferred to a 1000-ml sedimentation cylinder and the coarse fraction was dried in a 500-ml beaker.

Upon removal from the oven and being allowed to cool, the dried coarse fraction was size graded with screens according to the wentworth scale using phi notation (Folk, 1968).

Sieves of 8 -inch diameter and $0.5-\varnothing$ increments were employed for the separation process. The fractions coarser than $1 \varnothing$ were hand brushed through the appropriate sieves; the remaining sieves were then shaken on a Ro-tap automatic shaking machine for $10 \mathrm{~min}$. The fraction removed from each 

sieve was weighed to the nearest $0.1 \mathrm{mg}$, with the $3.0-, 3.5-$, and 4.0- $\varnothing$ fractions saved for later analysis.

Pan fractions obtained during the shaking of the coarse fractions were placed ir the 1000-ml cylinder containing the respective fine fraction for that subsample. A peptizing agent was added to each cylinder and a $0.5-\varnothing$ interval separation was performed by pipette. Wadell's correction of Stokes law at $20 \mathrm{C}$ was used to determine the settling velocities of the particles involved. Each $20-\mathrm{ml}$ pipette fraction was dried in a 50-ml beaker and weighed to the nearest $0.1 \mathrm{mg}$, subtracting the weight of the peptizing agent (Calgon).

When cumulative fraction weights reaching 95\% of the total weight were attained, the remaining sediments were combined as a final fraction.

\section{B. COMPUTER ANALYSIS OF RAN DATA}

Carter (1971) has prepared a size analysis program for use on the IBM 360 computer which will give an output using the statistical parameters of Folk and Ward (1957). In addition gravel-sand-silt-clay relationships, along with Trask values and Inman values are supplied.

\section{BATHYMETRIC PROFILES}

The bathymetric records and $3.5 \mathrm{kHz}$ profiles were studied from the viewpoint of linking sediment size distributions and discontinuities with bottom features. Thus, concentration was placed upon looking for irregularities in the profiles while temporarily disregarding the generally smooth bottom. 



\section{PRESENTATION OF DATA}

\section{A. TEXTURE OF SEDIMENTS}

Statistical results of the computer output are presented in tabular form giving the gravel-sand-silt percentages and Folk and Ward parameters. The term gravel is used in this work in its commonly applied sense, i.e., particles between -1.00 and $-6.00 \varnothing($ Folk, 1968). Those stations where no sediment sample was obtained are marked with an asterisk in Table II.

\section{Mean Grain-Size}

The mean grain-size of the sediments on the continental shelf ranged from -1.69 (Sample 66) to $3.53 \varnothing$ (Sample 37) (Fig. 4).

The gravel-sand-silt relationships are plotted (Fig, 5) on one face of the tetrahedron used by Krumbein and Sloss (1963). By percentages, there was little veriation in text re with 1 sample classified as silty-sand, 2 as sandy-gravel, 11 as pebbly-sand and 52 as sand. The finer sediments seem to be concentrated along the center of the shelf at depths of 40 to $60 \mathrm{fm}$ in both the north and south. There is a marked increase in grain-size at the shelf break. Above the lower branch $(\mathrm{M}-2)$ of the Monterey Canyon an area of very uniform material varying from $0.76 \varnothing$ in $55 \mathrm{fm}$ to $0.49 \varnothing$ in $30 \mathrm{fm}$, bisects the shelf.

A plot of mean grain-size vs depth (Fig. 6) shows grouping of the shallow and deep sediments toward the coarser 



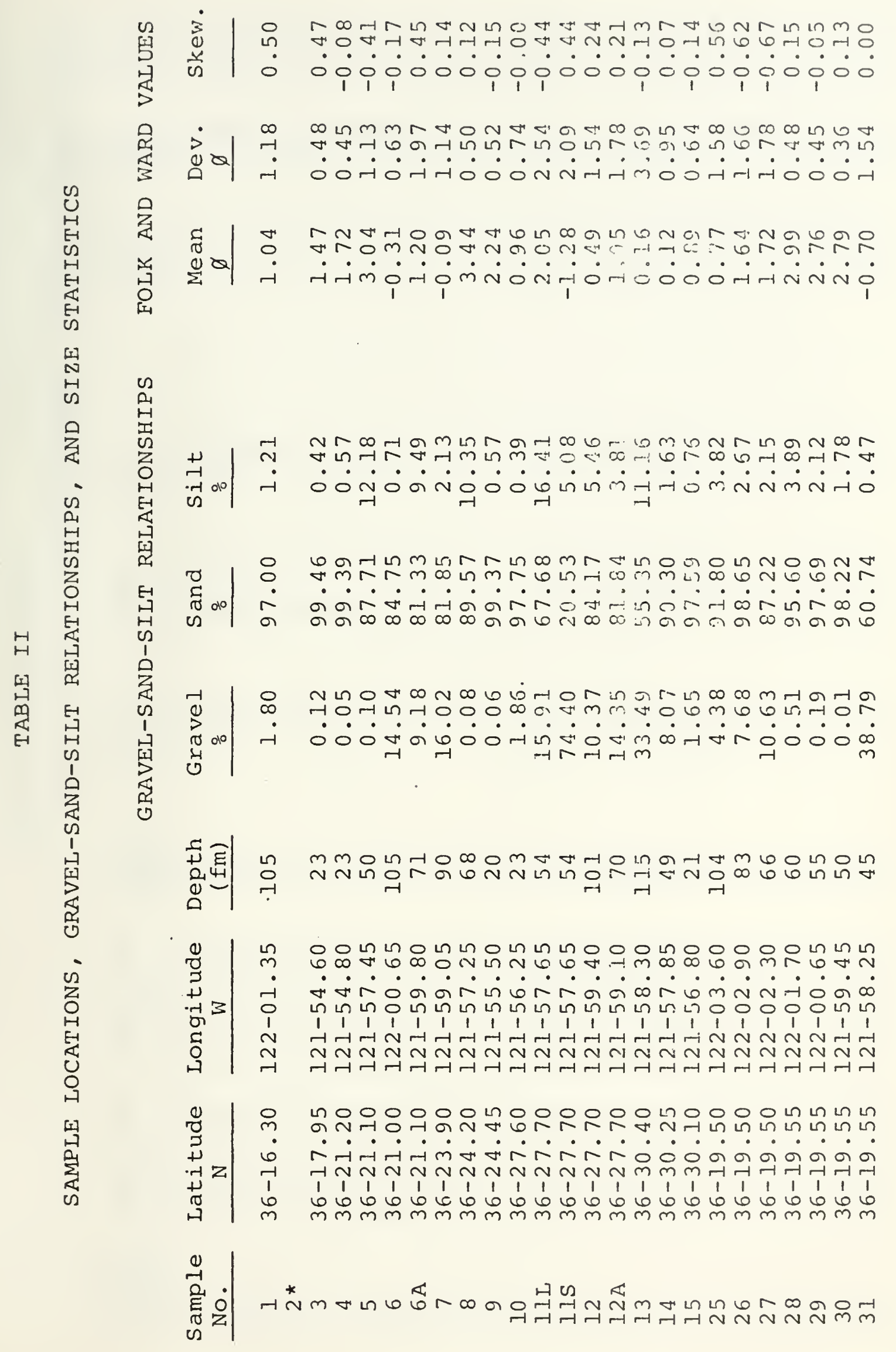



3 $\mid$ an $m+m$ r. ก. $00000000000 \%$

$\therefore \quad 0 m m 0 m \pi n$ n

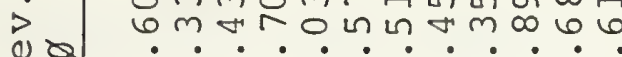
ब $\dot{0} \dot{0} \dot{0} \dot{0} \dot{0} \dot{0} \cdot$

द ROサmomNmolam U ○ं $\dot{0} \dot{\circ} \dot{m} \dot{m} \dot{0} \dot{0} \dot{0}$

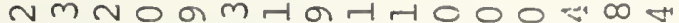

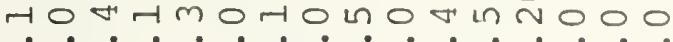
0000000000000000

○ N N N

$\infty$ \& 6 -

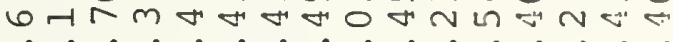
- 0 0000000 0 indó0. I am

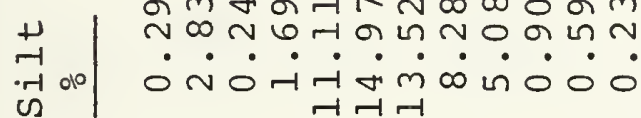

Arhm 2 m $m \rightarrow m \infty 00$ in $\ln$ in

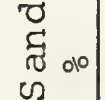
.. . . . . .

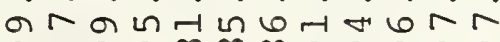
ă $\sigma$ a $\infty \infty$ a

Tomn $m 0 \pi+\infty 00 \pi 04 \infty \pi$

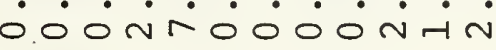
岳氞 인

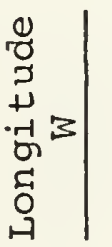

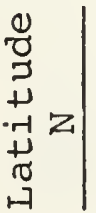
م o on m no no

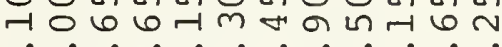
ก

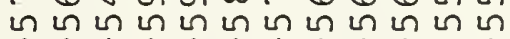
$1,1,1,1,1,1,1$

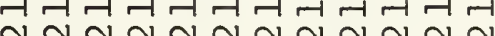
ח N N N N N N N N N N

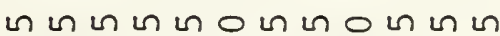

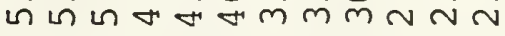
बंன் $\dot{\sim} \dot{\sim} \dot{\sim} \dot{\sim} \dot{\sim} \dot{\sim} \dot{\sim}$ $\pi-H \sim \sim N \sim N \sim N N$

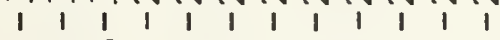
ต o o o onomann mo m th m

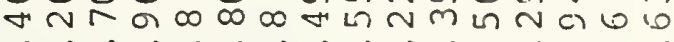

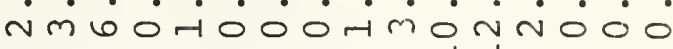
$\rightarrow-1$

NHogoon m n \%०० \%

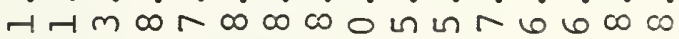
uráa áa a a $\infty \infty_{\infty} \infty$ la a

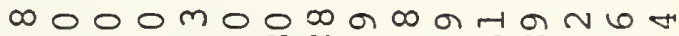

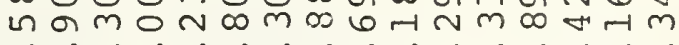
ம் mong

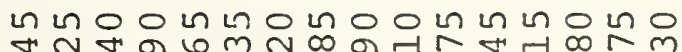
$\cdot \cdot \cdot \cdot \cdot \cdot \cdot \cdot \cdot \cdot \cdot \cdot \cdot \cdot \cdot$

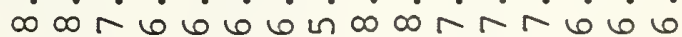

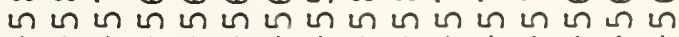
$\begin{array}{llllllllllllllllllllllll}1 & 1 & 1 & 1 & 1 & 1 & 1 & 1 & 1 & 1 & 1 & 1 & 1 & 1 & 1\end{array}$

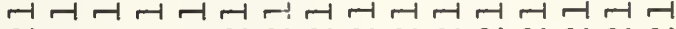

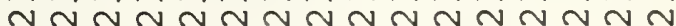

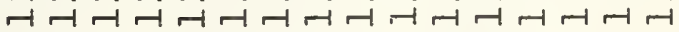

o $0000000 \mathrm{~m} 0 \mathrm{~m}$ in 000 $0000000066 \mathrm{n}$ H نं ن N N N N N N N N N N N $\begin{array}{llllllllllllllll}1 & 1 & 1 & 1 & 1 & 1 & 1 & 1 & 1 & 1 & 1 & 1 & 1 & 1 & 1 & 1\end{array}$ m  



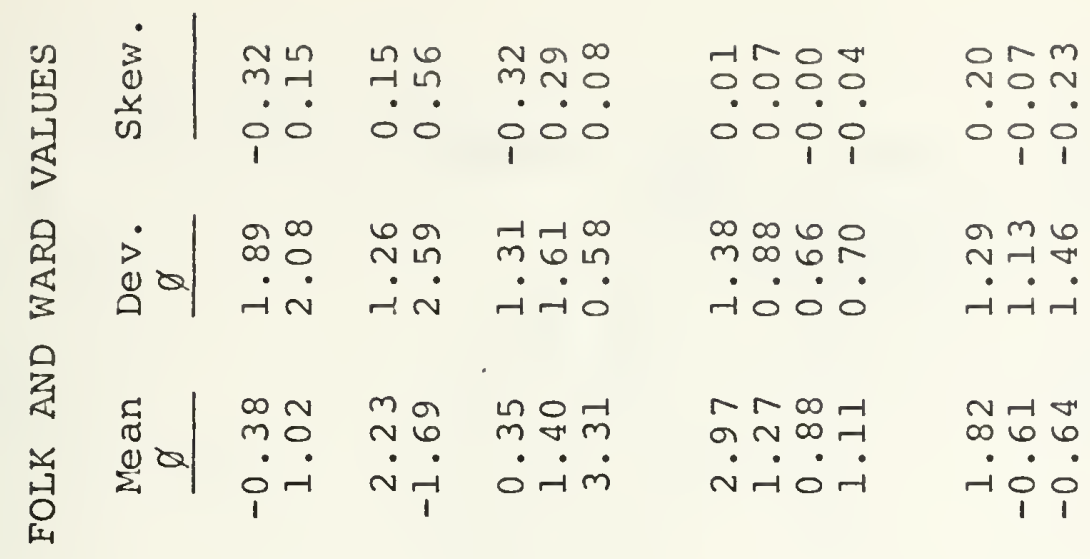

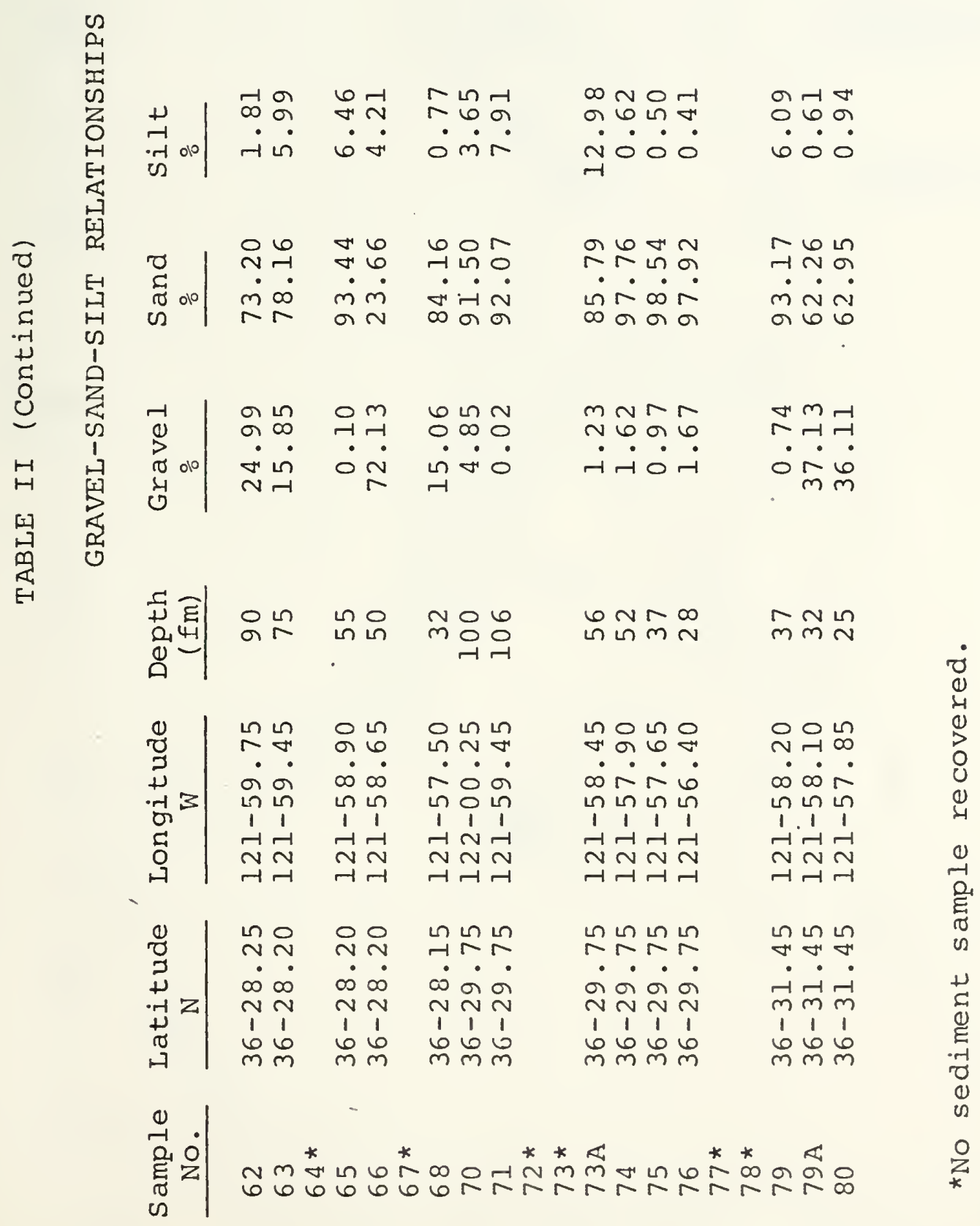





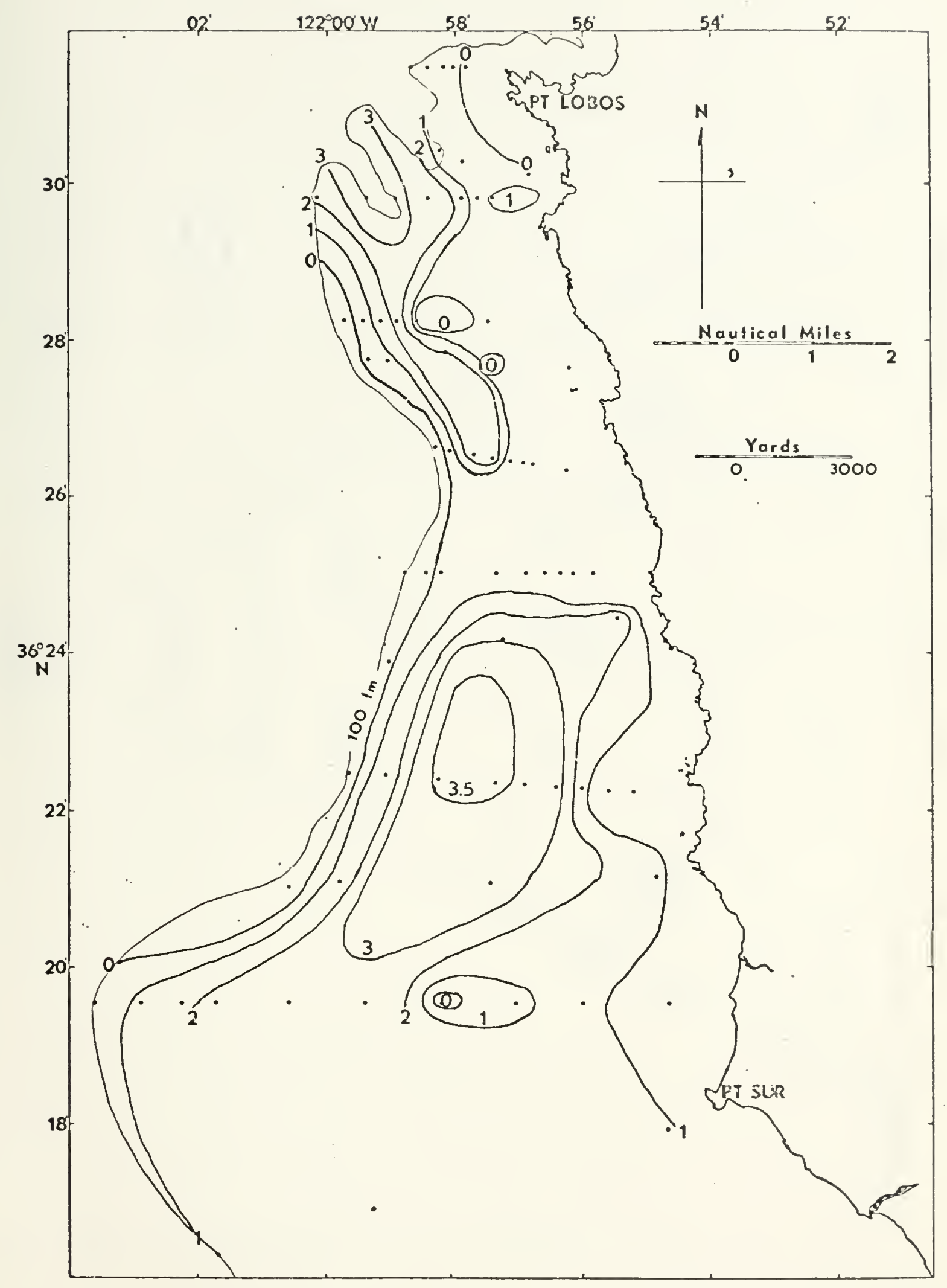

Fig. 4 Mean Grain-Size Distribution. Contours in $\varnothing$. 



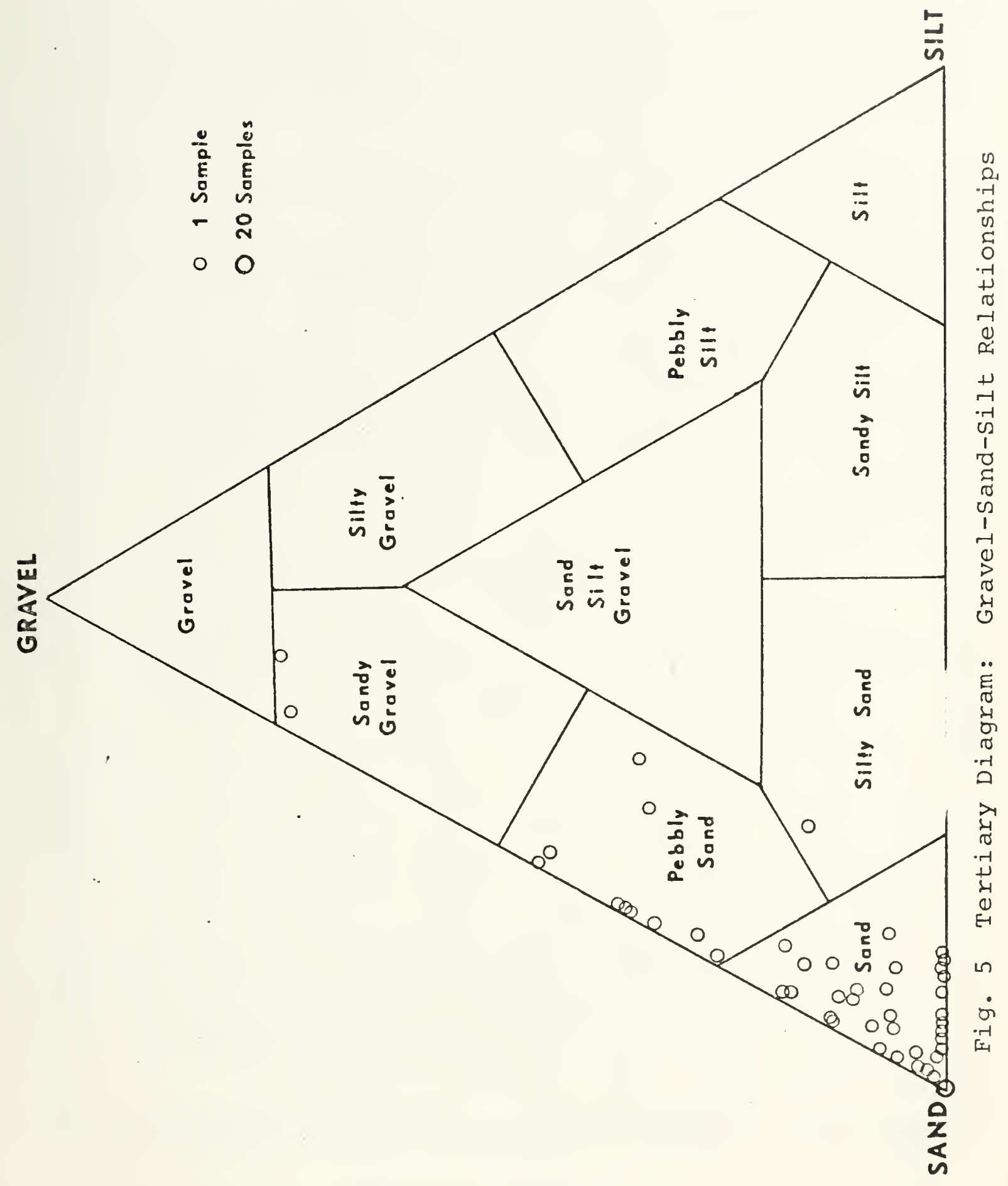





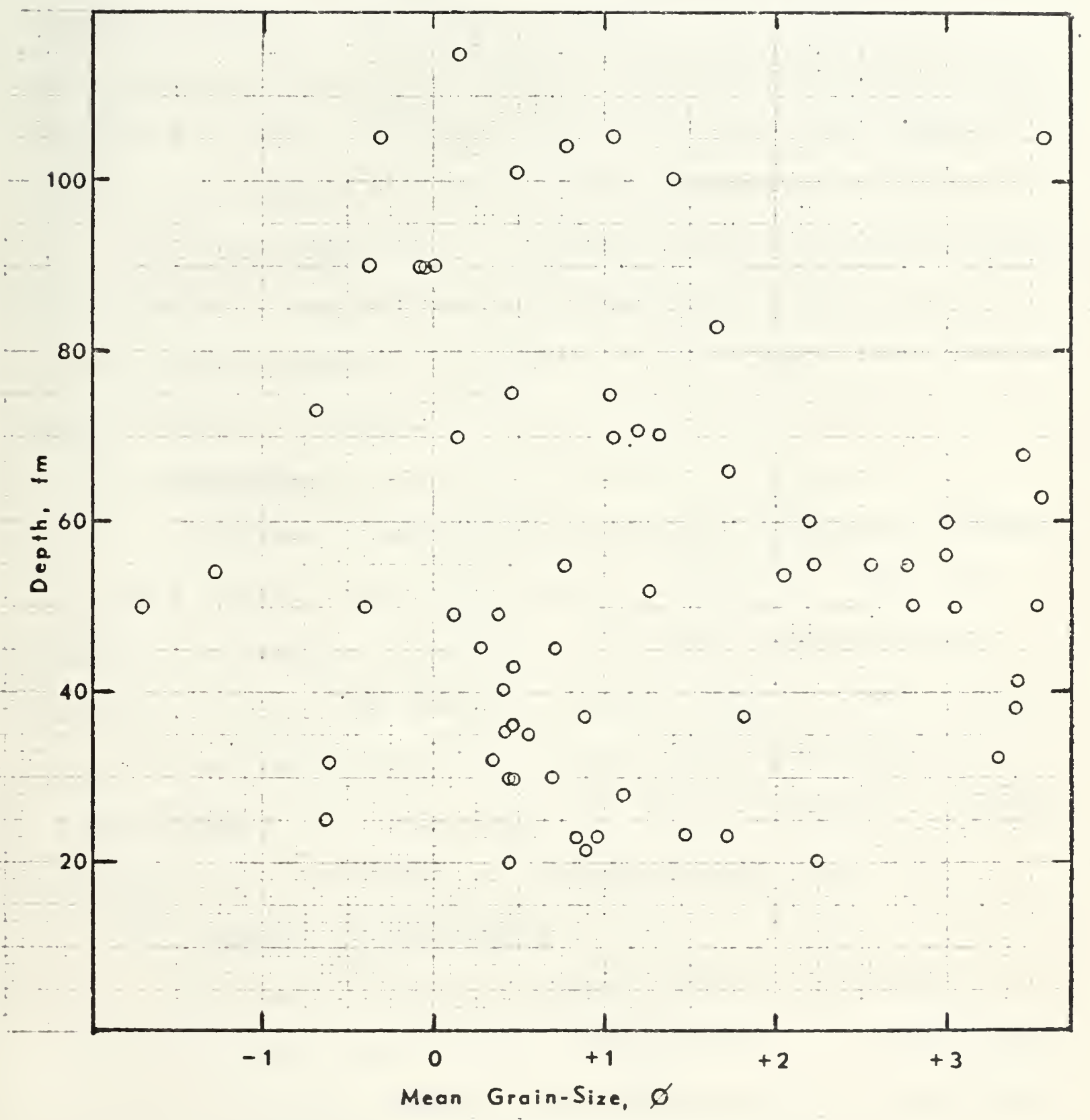

Fig. 6 Mean Grain Size vs Depth 
end of the graph, while the mid-depth sediments are found at the finer end of the plot.

2. Standard Deviation

The values of standard deviation ranged from 0.33 to $3.69 \varnothing($ Fig. 7). All of the samples taken along the shelf break had poor to very poor sorting ( 1.36 to $2.20 \varnothing)$, while the samples taken close to shore were generally well sorted $(0.43$ to $0.74 \varnothing)$. The mean grain-size variation within each of the two regions usually varied by less than $0.5 \varnothing$. A plot of mean grain-size vs standard deviation (Fig. 8) shows that the best sorting occurs in sediments finer than $3.0 \varnothing$. Also several samples in the 0.0 to $1.0 \varnothing$ range from shallow water are well sorted.

\section{Skewness}

Skewness values ranged from -0.67 to 0.56 (Fig. 9). The only pattern which appeared to develop was that the majority of samples from the shelf break had a positive skewness and all the samples from the shallow areas (less than $30 \mathrm{fm}$ ) were negatively skewed, with the exception of sample number 3. There seemed to be no discernible trends in the plot of skewness vs mean grain-size (Fig. 10).

\section{Bimodal Distributions}

In choosing which samples would be classified as bimodal an arbitrary selection was devised. If the sample had more than one mode and the primary mode contained less than $75 \%$ of the total weight, then the sample was designated as being bimodal. Of all the samples, 14 were found to be 



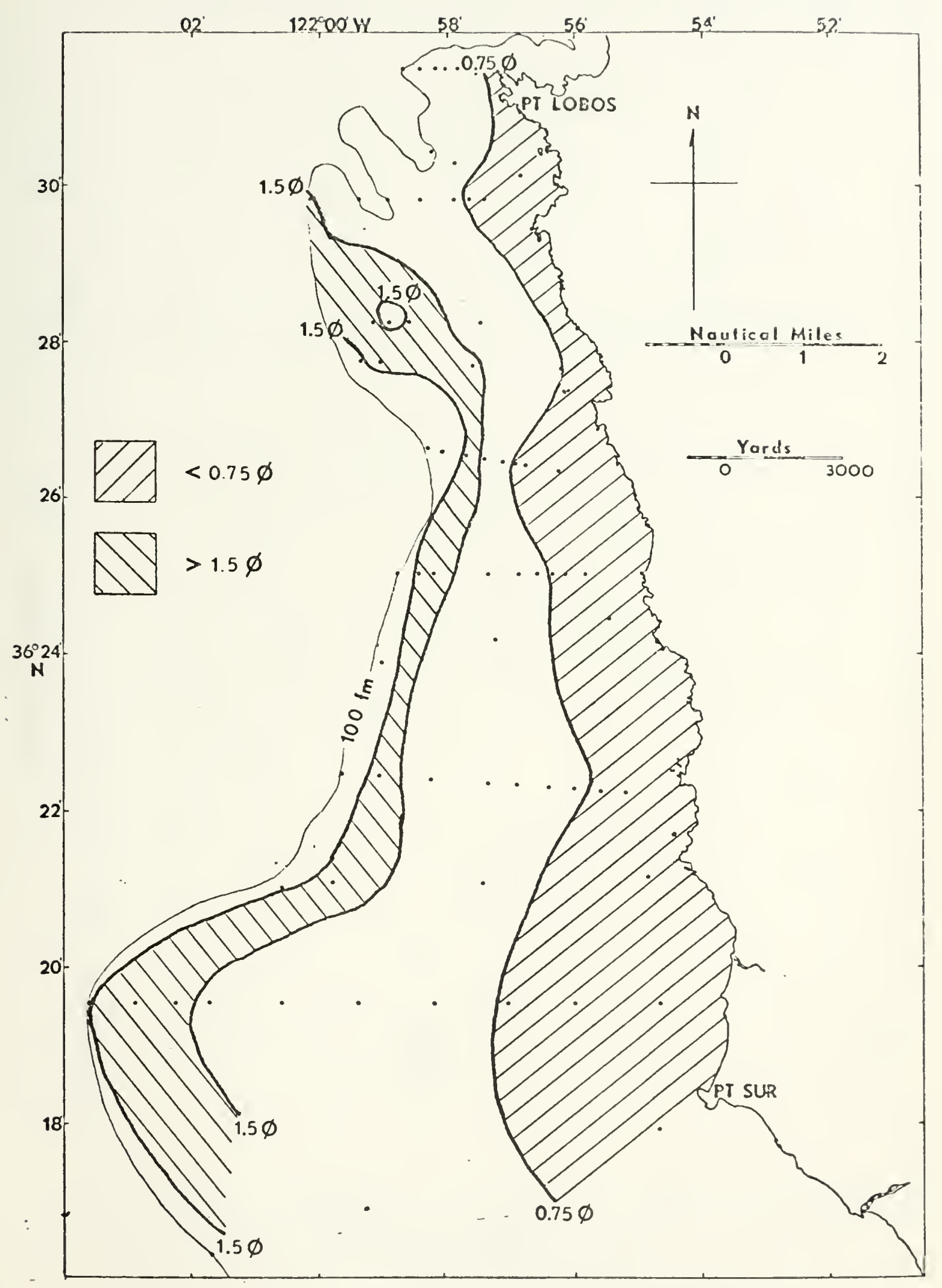

Fig. 7 Standard Deviation Distribution 



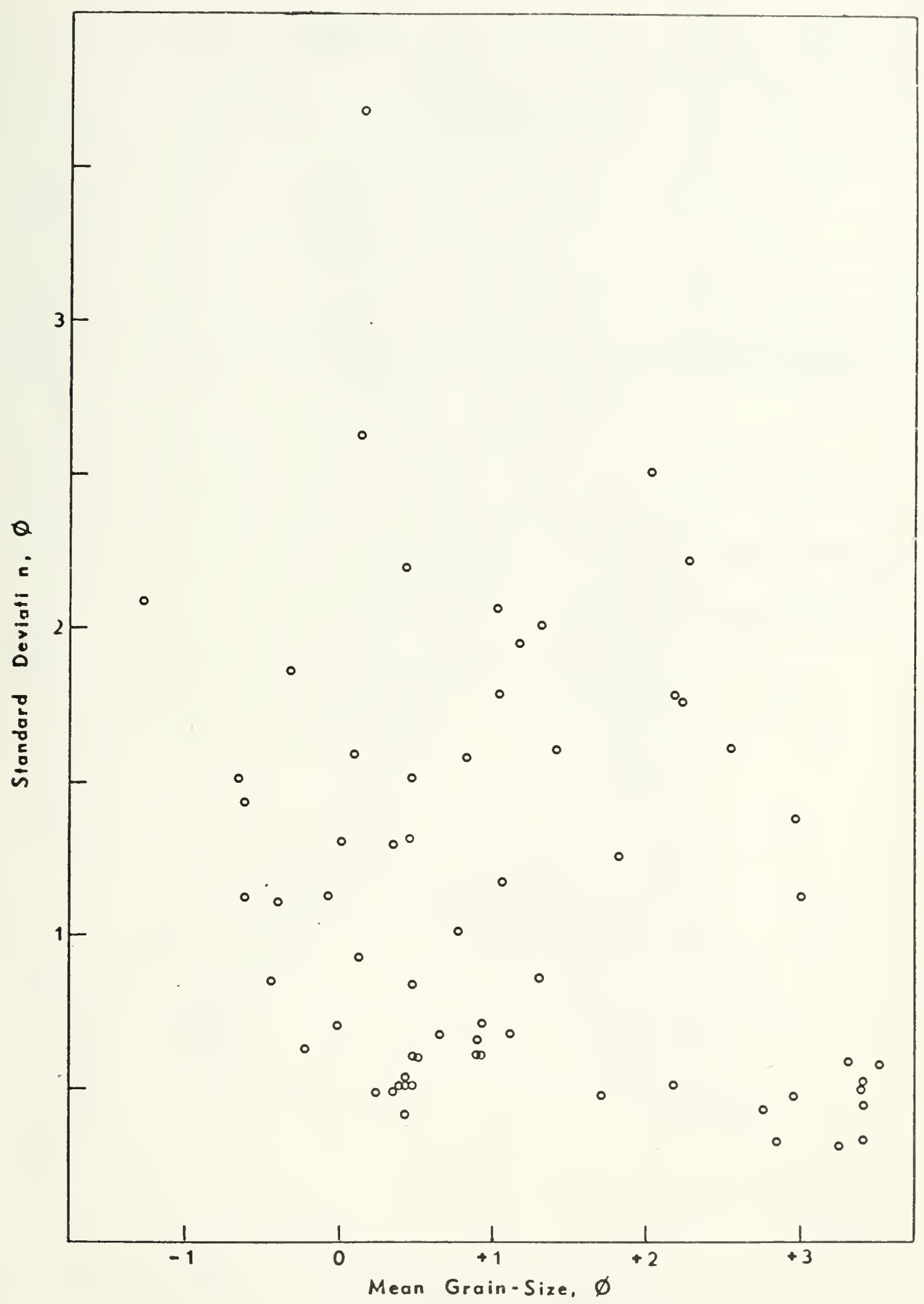

Fig. 8 Mean Grain-Size vs Standard Deviation 



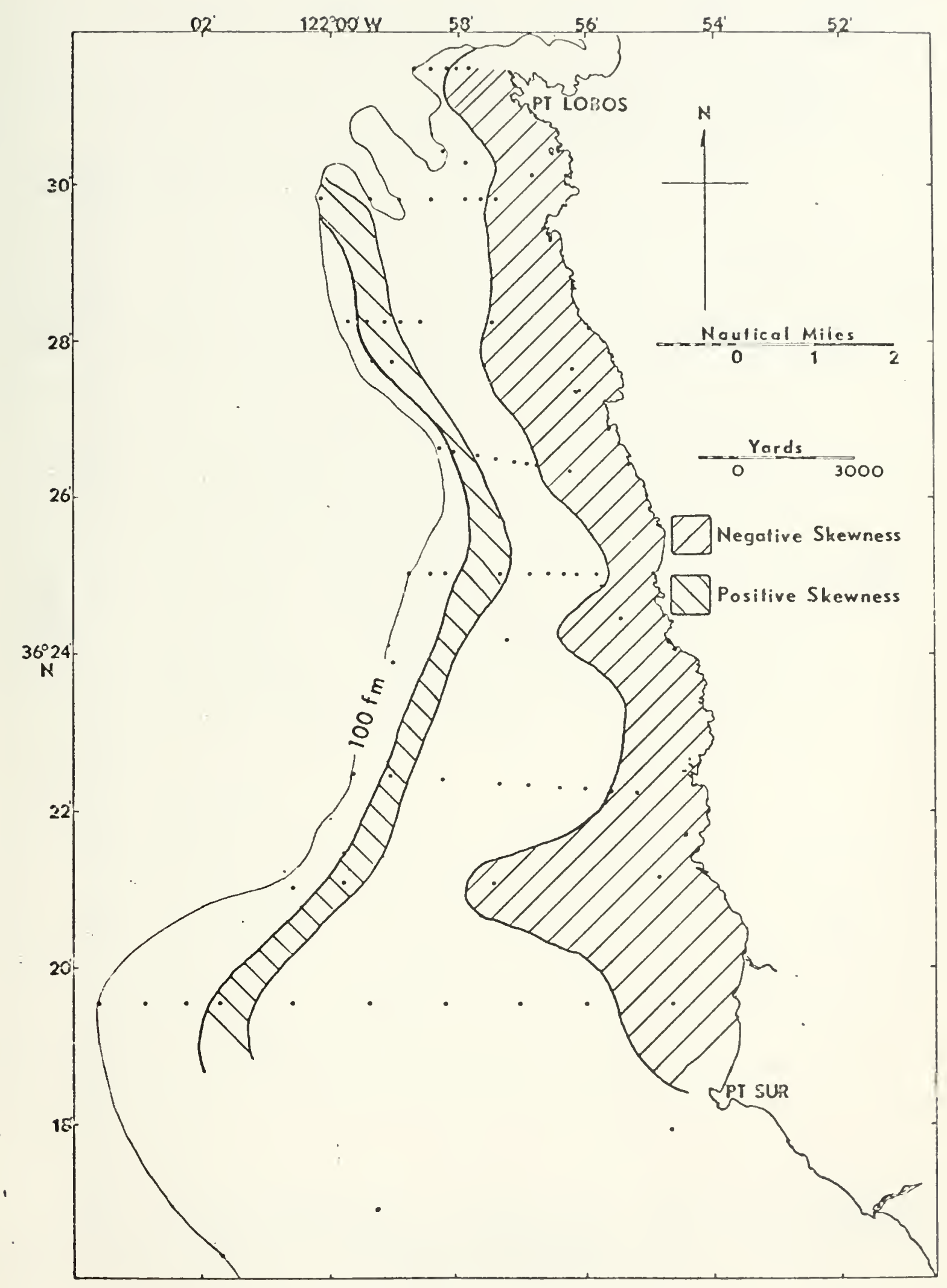

Fig. 9 Skewness Distribution 



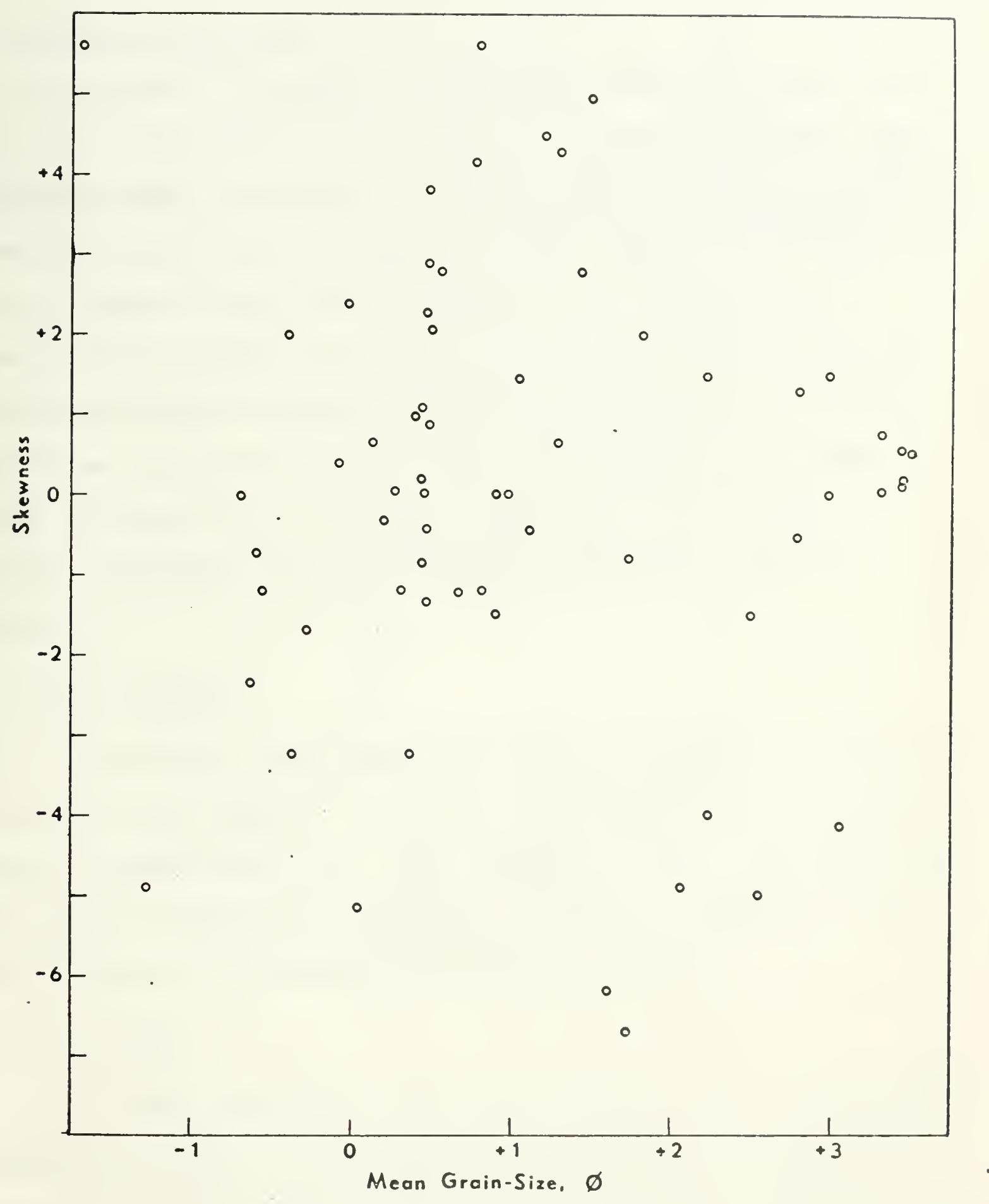

Fig. 10 Mean Grän-Size vs Skewness 

bimodal (Fig. 1l). All of these samples fell within the depth range of 55 to $115 \mathrm{fm}$; however, there were many other samples in this depth range not classified as bimodal.

\section{B. PEBBLE COMPOSITION}

In studying the pebble composition, samples $13,31,46$, 47, and 62 were found to contain quartz diorite pebbles from the Santa Lucia Formation. Andesite pebbles from the Carmelo Formation were found in samples 46,62 , and 66 ; additional felsite pebbles were found in sample 31. Mudstones were discovered in samples 115 and 66 , with the latter also containing sandstone and Miocene Monterey cherty shale, while the former contained shale. Gneiss and chert pebbles were found in sample 31. A granule conglomerate composed of angular fragments with a calcareous cement was found in sample 46 .

\section{SHELL CONTENT}

No analytical measurement was made of the shell content in each of the samples. However, notice was taken of several samples which seemed, by visual estimate, to be predominately composed of calcareous biological detritis. Samples 58, 68, and 79 appear to be entirely biological remains.

\section{BATHYMETRY}

of all the bathymetric features studied, only two displayed linear continuity. These were the shelf break occurring at about $70 \mathrm{fm}$ and an exposed fault scarp having, in general, 20-m relief (Fig. 12 and 13). 



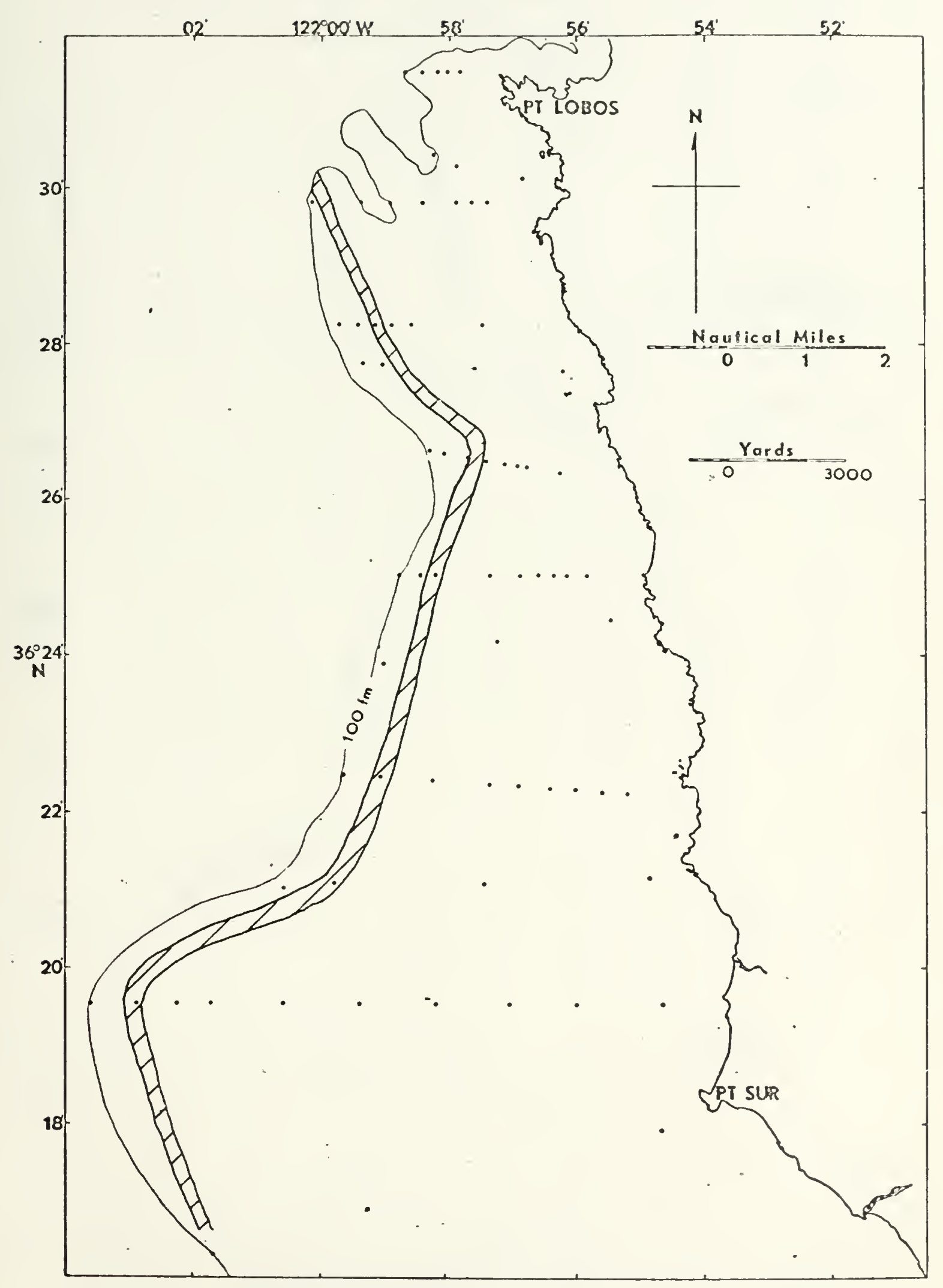

Fig. Il Bimodal Sample Distribution 



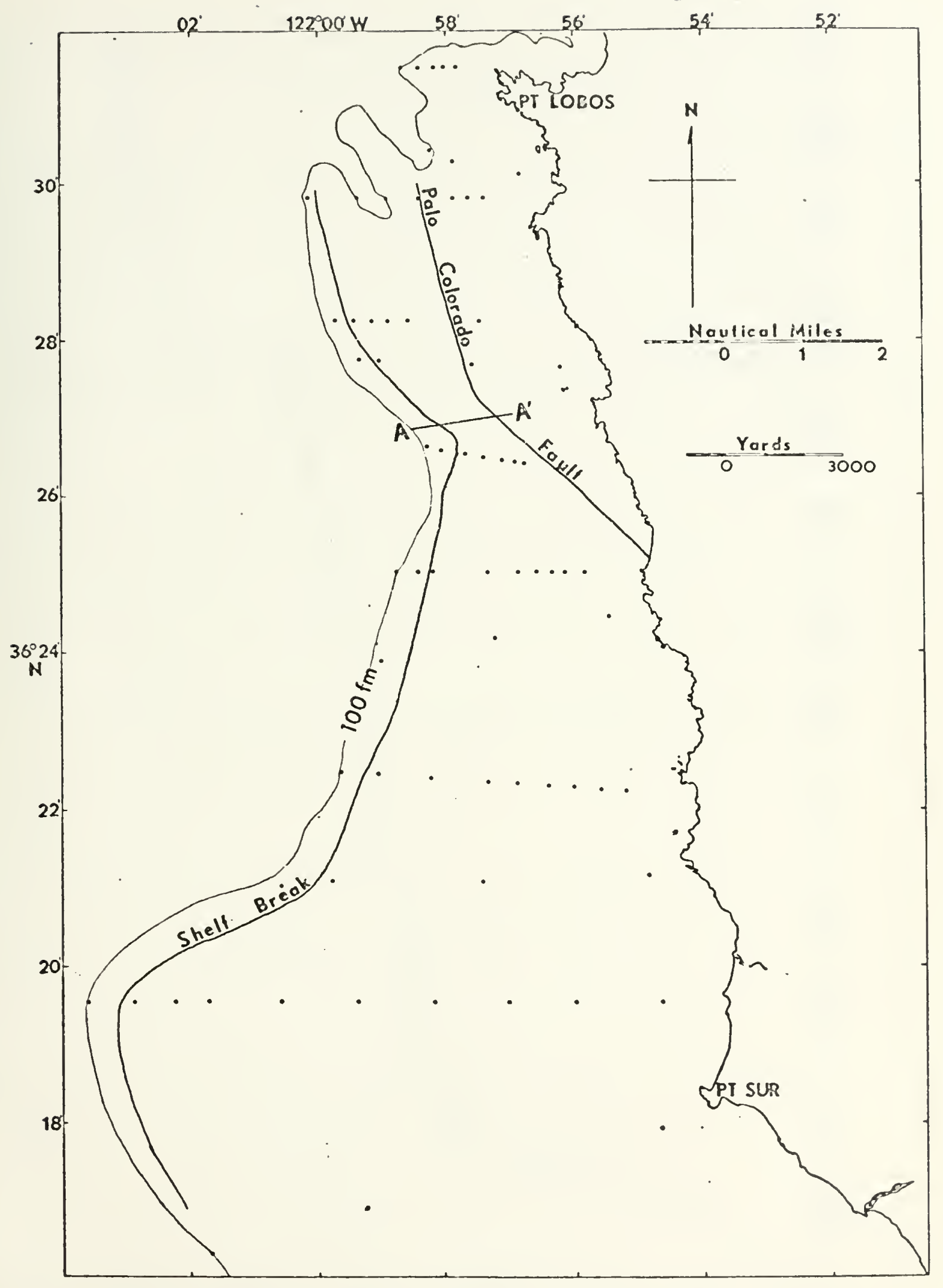

Fig. 12 offshore Extension of Palo Colorado Fault and Location of Continental Shelf Break 



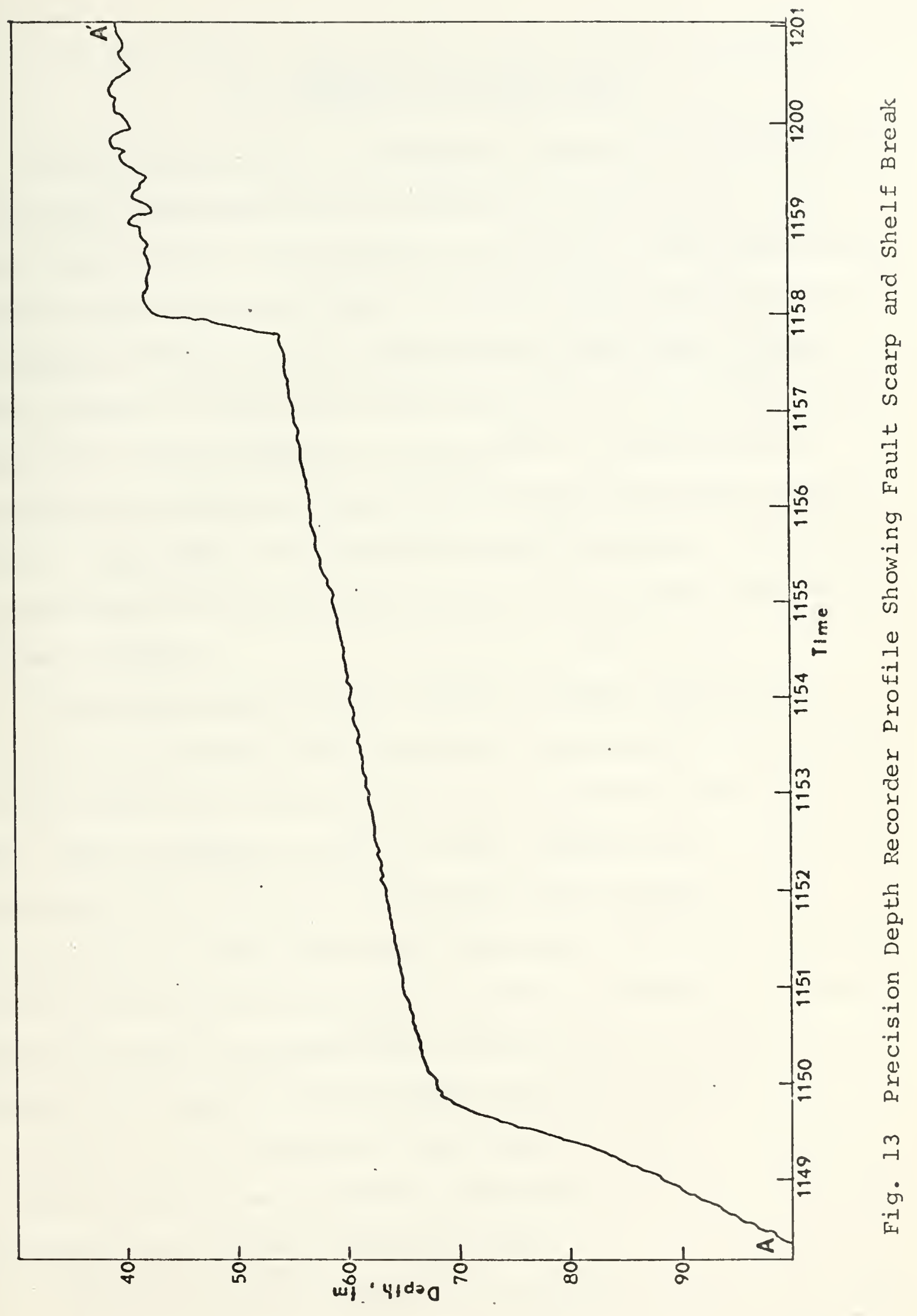





\section{SUMMARY AND CONCLUSIONS}

Three distinct belts of sediments appear on the central California continental shelf between Pt. Lobos and Pt. Sur. The outermost belt, consisting of relatively coarse sediment, occurs along the shelf break. Down the center of the shelf in depths of 35 to $65 \mathrm{fm}$ a discontinuous wide band of fine sands occurs. Within the widest part of the central band are found the finest sediments on the shelf. A second sharp gradient in mean size occurs between the central and coastal belts. Throughout the coastal belt the sediments, composed predominately of medium sand-sized particles, are moderately to well sorted.

A plot of those samples having a bimodal distribution follows very closely the location of the break in the continental shelf as it starts down the continental slope (Fig ll). The coarse fragments found in these samples give a strong indication that this is a submerged beach terrace. The coarseness of these samples is not readily apparent from the mean grain-size distributions, due to the presence of recently deposited fine fractions which tend to reduce the mean grainsize of the samples. The results of work in Monterey Bay by Galliher (1932), Monteath (1965), Yancey (1968), and Malone (1970) confirm that a similar coarsening of sediments occurs near the shelf break in Monterey Bay.

The sedimentation patterns on the shelf indicate that the area is being influenced by the canyons which lead from the 

shelf to the Monterey and Carmel Canyons. In the middle of the area the up- and down-canyon currents are washing the sediments, leaving the coarse, well sorted sediments in a belt across the shelf. The primary source of the sediments appears to be from the weathering of the coastal rock formations, with distributions from wave actions, as indicated by the unimodal . nature of the deposits out to the shelf break. Tongues of negatively skewed sediments extending outward from the coast indicate that the streams of the area are a secondary source of sediments. The fine fractions from these water-borne sediments are deposited along the center of the shelf.

Results of the bathymetric soundings indicate that the offshore extension of the Palo Colorado Fault follows the position charted by Dohrenwend (1971). However, northward of that location, the fault appears to bend through the branch of the Carmel Canyon as indicated in Fig. 12. The exposed $20-\mathrm{m}$ scarp is evidence of very slow sedimentation rates on the shelf (Fig. 13). This slow sedimentation rate is also supported by the presence of deposits composed almost entirely of calcareous biological detritis. Dohrenwend (1971) suggests that there may be up to $400 \mathrm{~m}$ of undifferentiated TertiaryQuaternary marine sediments on the down side of the fault. Thus, the Palo Colorado Fault in this area has at least $420 \mathrm{~m}$ of dip-slip displacement although it may be primarily of rightlateral strike slip displacement north of the study area in Monterey Bay (R. S. Andrews, personal communication). 



\section{SUGGESTIONS FOR FURTHER STUDY}

Much research still remains to be accomplished along this section of continental shelf. Currently in progress are a gravity survey and heavy mineral analysis of the sediments being conducted by the Naval postgraduate School.

Other studies of the area could include:

1. carbon, carbonate, and organic nitrogen analysis of the sediments;

2. current and water column structure and fluctuation determinations along the shelf;

3. study of the three submarine canyon branches in the - area. 



\section{BIBLIOGGRAPY}

1. Carter, I. S. 1971. Recent Marine Sediments of Carmel Bay California. M.S. Thesis, Naval Postgraduate School, Monterey, Ca. $61 \mathrm{p}$. (Unpublished Report)

2. Dohrenwend, J.C. 1971. Marine Geology of the Continental Shelf between Point Lobos and Point Sur, California: Is Reconnaissance. M.S. Thesis, Stanford University, Stanford, Ca. $60 \mathrm{p}$. (Unpublished Report)

3. Folk, R.I. 1968. Petrology of Sedimentary Rocks. Hemphill's Austin, Tex. $170 \mathrm{p}$.

4. Folk, R.L., and W.C. Ward. 1957. Brazos River Bar: A Study in the Significance of Grain Size Parameters. J. Sediment. Petrol. 27(1):3-26.

5. Galliher, E.W. 1932. Sediments of Monterey Bay, California. State of California, Report of the State Mineralogist $28(1): 42-79$.

б. Krumbein, W.C., and F.J. Pettijohn. 1938. Manual of Sedimentary Petrology. Appleton-Century-Crofts, Inc., N. Y. 549 p.

7. Krumbein, W.C., and I.I. Sloss. 1963. Stratigraphy and Sedimentation, 2nd ed. W.H. Freeman and Co., San Francisco, Ca. $660 \mathrm{p}$.

8. Malone, J.H. 1970. A Pebble-Cobble Deposit i.s Monter:y Bay, California. M.S. Thesis, Naval Postgraduate School, Monterey, Ca. $48 \mathrm{p}$. (Unpublisheã Report)

9. Monteath, G.M. 1965. Environmental Analysis of the Sediments of Southern Monterey Bay, California. M.S. Thesis, Naval Postgraduate School, Monterey, Ca. $87 \mathrm{p}$. (Unpublished Report)

10. Rusnak, G.A. 1966. The Continental Margin of Northern and Central California. California Division of Mines and Geology Bulletin 190: 325-335.

11. Shepard, F.P. 1963. Submarine Geology, 2nd ed. Hlarper and Row, N. Y. 557 P.

12. Shepard, F.P. and K.O. Emery. 1941. Submarine Topography off the California Coast: Canyons and Tectonic Interpretation. Geol. Soc. Amer. Spec. Paper 31.171 p. 

13. Sverdrup, H.U. and N. W. Johnson, and R.H. Fleming. 1942. The Oceans, Their Physics, Chemistry, and General Biology. Prentice-Hall, Inc., Englewood Cliffs, N. J. $1087 \mathrm{p}$.

14. Taliaferro, N.I. 1944. Cretaceous and Paleocene of Santa Lucia Range, California. Bull. Am. Assoc. Petro. Geol. 28(4):449-521.

15. Trask, P.D. 1926. Geology of Point Sur Quadrangle, California. University of California Publications, Bulletin of the Department of Geologic Sciences $16(6): 119-186$.

16. Yancey, T.E. 1968. Recent Sediments of Monterey, California. University of California Hydraulic Engineering Laboratory, Tech. Rep. He1-2-18. 145 p. 

1. Defense Documentation Center

Cameron Station

Alexandria, Virginia 22214

2. Library, Code 0212

Naval Postgraduate School

Monterey, California 93940

3. Professor R. S. Andrews, Code $58 \mathrm{Ad}$

Department of Oceanography

Naval Postgraduate School

Monterey, California 93940

4. Department of Oceanography, Code 58

Naval Postgraduate School

Monterey, California 93940

5. LT. H. P. Colomb, USN

SMC 2144

Naval Postgraduate School

Monterey, California 93940

6. Mr. Frederick A. Meyer

Environmental Resources Section

Supervisor, Dept. of Parks and Recreation

State of California - Resources Agency

P. O. Box 2390

Sacramento, California 95811

7. Office of Naval Research

Code $480 \mathrm{D}$

Arlington, Virginia 22217

8. Mr. Don Rich

California Department of Parks and Recreation

District 4 Headquarters

2211 Garden Road

Monterey, California 93940

9. Professor W. C. Thompson, Code 58th

Department of Oceanography

Naval Postgraduate School

Monterey, California 93940 

No. Copies

10. Oceanographer of the Navy

The Madison Building

$732 \mathrm{~N}$. Washington

Alexandria, Virginia 22314

11. Master

$\mathrm{R} / \mathrm{V}$ ACANIA

Department of Oceanography, Code 58

Naval Postgraduate School

Monterey, California 93940 

DOCUMENY CONTROL DATA.R \& D

falion nust be entered whem the overall repopt is clessllied) Q INATINGACTIVITY (Corposale author)

Javal Postgraduate School lonterey, California 93940

Unclassified 2b. GROUP

EORT TITLE

Recent Marine Sediments of the Central California Continental thelf between Point Lobos and Point Sur

ICRIPTIVE NOTES (JYPe ol repors end.Inclusive dales)

Master's Thesis; March 1973

- HOR(S) (First riamo, middle intliel, last nemo)

Herbert Palfrey Colomb, Jr.

\begin{tabular}{|c|c|c|}
\hline $\begin{array}{l}\text { ORT DATE } \\
\text { March } 1973\end{array}$ & $\begin{array}{l}\text { 7a. TOTAL NO. OF PAGES } \\
44\end{array}$ & $\begin{array}{c}\text { 7b. NO. OF REFS } \\
16\end{array}$ \\
\hline \multirow[t]{3}{*}{ INTRACTORGRANTNO. } & \multicolumn{2}{|c|}{ 94. ORIGINATOR'S REPOIAY NUMEERIS) } \\
\hline & & \\
\hline & \multicolumn{2}{|c|}{$\begin{array}{l}\text { ob. OTHER REPORT NOLS\& (fAny other numbero thet may bo easlenod } \\
\text { (his report) }\end{array}$} \\
\hline
\end{tabular}

STRIBUTION STATEMENT

Approved for public release; distribution unlimited.

Seventy sediment samples were collected from the continental helf between Pt. Lobos and Pt. Sur for textural analysis to letermine their statistical properties. Based upon the parameters if mean grain-size, standard deviation, and skewness, three listinct belts of sediment were found. Along the coast the sediments lere composed of medium sand-sized, moderately to well sorted larticles. Down the center of the shelf a discontinuous band of 泣e sand occurs in depths of 35 to $65 \mathrm{fm}$. The outer band appears : o follow the break in the continental shelf and is composed of :elatively coarse sediment.

Two bathymetric and $3.5 \mathrm{kHz}$ seismic profilin: cruises were nade through the area. The results of these cruises indicate that the offshore extension of the Palo Colorado Fault follows a branch of the Carme? Submarine Canyon.

The primary source of sediments appears to bxe weathering of coastal rock formations, with sediment distribution due to wave action. 

CALIFORNIA CONTINENTAL SHELF

MARINE SEDIMENTS

SEDIMENT ANALYSIS

DD FORA 1473 (BACK)
S/N 0101-807-6821









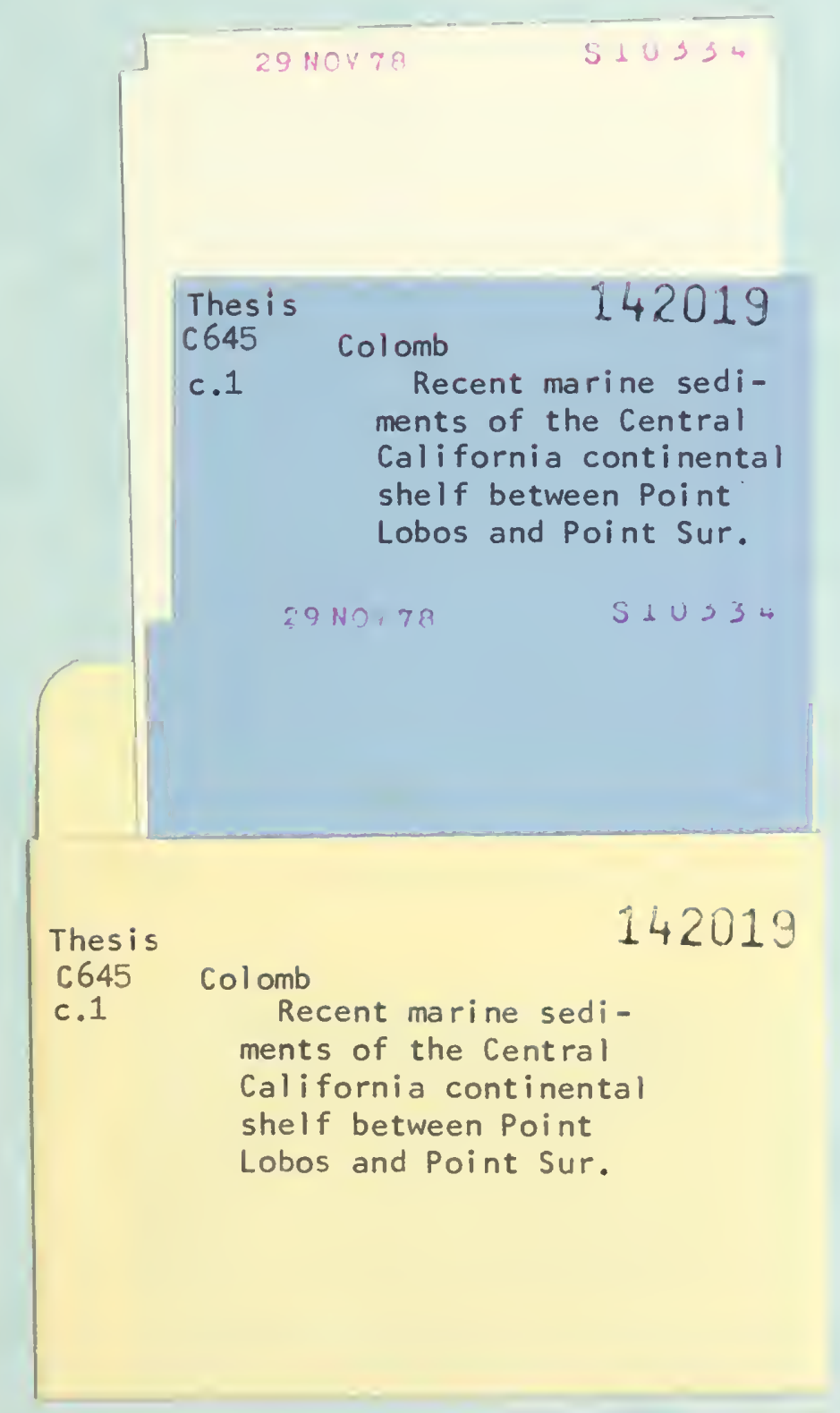


thesC645

Recent marine sediments of the Central C

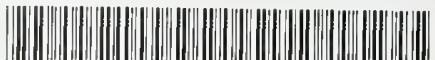

32768002083941

DUDLEY KNOX LIBRARY 